\author{
Ö. Özer ${ }^{1}$, D. Bellaouar ${ }^{2}$ \\ ${ }^{1}$ Kirklareli University, Turkey; \\ ${ }^{2}$ University 08 Mai 1945 Guelma, Guelma, Algeria \\ (E-mail: ozenozer39@gmail.com)
}

\title{
Some results on a special type of real quadratic fields
}

In this paper, we determine the real quadratic fields $Q(\sqrt{d})$ coincide with positive square-free integers $d$ including the continued fraction expansion form of $w_{d}=[a_{0} ; \underbrace{\overline{7,7, \ldots, 7}, a_{\ell}}_{\ell-1}]$. Furthermore, we deal with determining fundamental units and Yokoi's $d$-invariants $n_{d}$ and $m_{d}$ in the relation to continued fraction expansion of $w_{d}$ where $\ell(d)$ is a period length of $w_{d}$ for the such type of real quadratic number fields $Q(\sqrt{d})$. The present paper improve the theory of fundamental unit which generates the unit group of real quadratic fields and also determine the special form of continued fraction expansion of integral basis element in real quadratic fields.

Keywords: continued fraction, real quadratic fields, fundamental unit, Yokoi's invariants, integer sequences, integer basic element.

\section{Introduction}

Some relations among i-th approachment of quadratic irrationals were proved by ElezoviA'c in [1] . Jeongho obtained lower bound for regulator of real quadratic fields by considering quadratic integers with fixed norm in [2]. In [3], Benamar et al. described polynomials and also gave lower bound of the number of some types of polynomials. Badziahin and Shallit confirmed the conjecture of Hanna and Wilson by considering specific type of continued fraction of real numbers and got some results on transcendental numbers in [4]. Zhang and Yue [5] described some congruences relations between the coffecients of fundamental unit of real quadratic fields and odd class number. Also, Tomita [6] gave some results on fundamental unit by use of the continued fraction expansion of integral basis element where period length is equal to 3. Clemens and his co-authors [7] explored some relationship between continued fraction expansion and infinite series representation for real numbers. Louboutin [8] obtained significant results on principal or non principal real quadratic fields as well as significant conditions for principality of continued fraction expansion. Tomita and Kawamoto [9] showed a relation between real quadratic fields of class number one and minimal type of the simple continued fraction expansion of certain quadratic irrationals. Both Sasaki [10] and Mollin [11] achieved many useful results on lower bound of fundamental unit for real quadratic number fields. Williams and Buck [12] got comparision between period length of $\sqrt{d}$ and $\frac{1+\sqrt{d}}{2}$. Besides, first author in this paper obtained some special results for different forms of continued fraction expansion of $w_{d}$ in [13] and [14] where $d \equiv 2,3(\bmod 4)$ is square-free positive integer. Also, in [15] she got significant results for varied types of continued fraction expansion of $w_{d}$ where $d \equiv 1(\bmod 4)$ or $d \equiv 2,3(\bmod 4)$ Yokoi defined $n_{d}$ and $m_{d}$ invariants important for class number problem [16-19]. Readers unfamiliar fundamental unit and continued fraction expansions are referred to books [11, 20-23].

Throughout this paper, $I(d)$ is the set of all quadratic irrational numbers in $Q(\sqrt{d})$, we say that $\alpha$ in $I(d)$ is reduced if $\alpha>1$ and $-1<\alpha^{\prime}<1$ where $\alpha^{\prime}$ is the conjugate of $\alpha$ and denoted by $R(d)$ is the set includes of all reduced quadratic irrational numbers in $I(d)$. Then, it is well known that any number $\alpha$ in $R(d)$ is purely periodic in the continued fraction expansion and the denominator of its modular automorphism is equal to fundamental unit $\epsilon_{d}$ of $Q(\sqrt{d})$. Yokoi's invariants are expressed by $m_{d}=\left[\left[\frac{u_{d}^{2}}{t_{d}}\right]\right]$ and $n_{d}=\left[\left[\frac{t_{d}}{u_{d}^{2}}\right]\right]$. it is also well known [[ $x]]$ represents the floor of $x$ for any number $x$.

In this paper, we deal with the problem for demonstrating the continued fraction expansions which have got partial constant elements equal each others and written as 7s (except the last digit of the period) according to period length for $d$ square-free integer $($ for $d \equiv 1(\bmod 4)$ or $d \equiv 2,3(\bmod 4))$. 
Moreover, we demonstrate the general parametrization of $d$ square-free positive integer and fundamental unit $\epsilon_{d}$ as well as $t_{d}, u_{d}$ the coefficents of fundamental unit. Additionally, we get fix on Yokoi's invariants for such types of real quadratic fields. Then, we give some results on fundamental units, continued fraction expansion and Yokoi's invariants with numerical Tables.

\section{Preliminaries and Basic Results}

In this section, readers can find some basic and important definitions and theorems for using our new results.

Definition 2.1. $\left\{\tau_{i}\right\}$ is a sequence defined by the following recurrence relation

$$
\tau_{i}=7 \tau_{i-1}+\tau_{i-2}
$$

for $i \geq 2$ where $\tau_{0}=0$ and $\tau_{1}=1$.

Lemma 2.2. [6]. For a square-free positive integer $d$ congruent to 1 modulo 4 , let $\omega_{d}=\frac{1+\sqrt{d}}{2}$, $a_{0}=\left[\left[\right.\right.$ omega $\left.\left._{d}\right]\right], \quad \omega_{R}=a_{0}-1+\omega_{d}$. Then $\omega_{d} \notin R(d), \quad$ but $\omega_{R} \in R(d)$ holds. Moreover for the period $l=\ell(d)$ of $\omega_{R}$, we get $\omega_{R}=\left[\overline{2 a_{0}-1, a_{1}, \ldots \ldots, a_{l-1}}\right]$ and $\omega_{d}=\left[a_{0}, \overline{a_{1}, \ldots \ldots, a_{l-1}, 2 a_{0}-1}\right]$. Furthermore, let $\omega_{R}=\frac{\left(P_{l} \omega_{R}+P_{l-1}\right)}{\left(Q_{l} \omega_{R}+Q_{l-1}\right)}=\left[2 a_{0}-1, a_{1}, \ldots \ldots, a_{l-1}, \omega_{R}\right]$ be a modular automorphism of $\omega_{R}$, then the fundamental unit $\epsilon_{d}$ of $Q(\sqrt{d})$ is given by the following formula

$$
\epsilon_{d}=\frac{t_{d}+u_{d} \sqrt{d}}{2}
$$

and

$$
t_{d}=\left(2 a_{0}-1\right) \cdot Q_{\ell(d)}+2 Q_{\ell(d)-1}, \quad u_{d}=Q_{\ell(d)},
$$

where $Q_{i}$ is determined by $Q_{0}=0, Q_{1}=1$ and $Q_{i+1}=a_{i} Q_{i}+Q_{i-1} \quad(i \geq 1)$.

Lemma 2.3. For a square-free positive integer $d$ congruent to 2,3 modulo 4 , let $\omega_{d}=\sqrt{d}, a_{0}=\left[\left[\omega_{d}\right]\right]$, $\omega_{R}=a_{0}+\omega_{d}$. Then $\omega_{d} \notin R(d)$, but $\omega_{R} \in R(d)$ holds. Moreover for the period $l=l(d)$ of $\omega_{R}$, we get $\omega_{R}=\left[\overline{2 a_{0}, a_{1}, \ldots \ldots, a_{l-1}}\right]$ and $\omega_{d}=\left[a_{0}, \overline{a_{1}, \ldots \ldots, a_{l-1}, 2 a_{0}}\right]$. Furthermore, let $\omega_{R}=\frac{\left(P_{l} \omega_{R}+P_{l-1}\right)}{\left(Q_{l} \omega_{R}+Q_{l-1}\right)}=$ $=\left[2 a_{0}, a_{1}, \ldots \ldots, a_{l-1}, \omega_{R}\right]$ be a modular automorphism of $\omega_{R}$, then the fundamental unit $\epsilon_{d}$ of $Q(\sqrt{d})$ is given by the following formula:

$$
\left.\epsilon_{d}=\frac{t_{d}+u_{d} \sqrt{d}}{2}=\left(a_{0}+\sqrt{d}\right) Q_{\ell(d)}+Q_{\ell(d)-1}\right\rangle 1
$$

and

$$
t_{d}=2 a_{0} \cdot Q_{\ell(d)}+2 Q_{\ell(d)-1}, \quad u_{d}=2 Q_{\ell(d)},
$$

where $Q_{i}$ is determined by $Q_{0}=0, Q_{1}=1$ and $Q_{i+1}=a_{i} Q_{i}+Q_{i-1},(i \geq 1)$.

Remark 2.4. Let $\left\{\tau_{n}\right\}$ be a sequence defined as in Definition 2.1. Then, we state that:

$$
\tau_{n} \equiv \begin{cases}0(\bmod 4), & n \equiv 0(\bmod 6) \\ 1(\bmod 4), & n \equiv 1,4,5(\bmod 6) \\ 3(\bmod 4), & n \equiv 2(\bmod 6) \\ 2(\bmod 4), & n \equiv 3(\bmod 6)\end{cases}
$$

where $n \geq 0$.

\section{Main Theorems and Results}

In this section, we present our results as follows:

Theorem 3.1. Let $d$ be the square-free positive integer and $\ell$ be a positive integer holding that $\ell$ is different from $0(\bmod 3)$ and $\ell>1$. We assume that parametrization of $d$ is

$$
d=\frac{\left(7+(2 t+1) \tau_{\ell}\right)^{2}}{4}+\left((2 t+1) \tau_{\ell-1}\right)+1
$$

for $t \geq 0$ positive integer. In this case, we get following: 
(1) If $\ell \equiv 1(\bmod 6)$ and $t \equiv 1(\bmod 2)$ positive integer then $d \equiv 2(\bmod 4)$ holds.

(2) If $\ell \equiv 2(\bmod 6)$ and $t \equiv 0(\bmod 2)$ positive integer then $d \equiv 3(\bmod 4)$ holds.

(3) If $\ell \equiv 4(\bmod 6)$ and $t \equiv 0(\bmod 2)$ positive integer then $d \equiv 3(\bmod 4)$ holds.

(4) If $\ell \equiv 5(\bmod 6)$ and $t \equiv 0(\bmod 2)$ positive integer then $d \equiv 2(\bmod 4)$ holds.

In this case, we obtain

$$
w_{d}=[\frac{(2 t+1) \tau_{\ell}+7}{2} ; \underbrace{\overline{7,7, \ldots, 7}}_{\ell-1},(2 t+1) \tau_{\ell}+7]
$$

and $\ell=\ell(d)$. Moreover, we have following equations:

$$
\begin{gathered}
\epsilon_{d}=\left(\frac{(2 t+1) \tau_{\ell}^{2}}{2}+\frac{7 \tau_{\ell}}{2}+\tau_{\ell-1}\right)+\tau_{\ell} \sqrt{d} ; \\
t_{d}=(2 t+1) \tau_{\ell}^{2}+7 \tau_{\ell}+2 \tau_{\ell-1} \quad \text { and } \quad u_{d}=2 \tau_{\ell}
\end{gathered}
$$

for $\epsilon_{d}, t_{d}$ and $u_{d}$.

Remark 3.2. Note that $d$ is not integer for $\ell \equiv 0(\bmod 3)$. That's why we assume that $\ell$ different from $0(\bmod 3)$.

Proof. We assume that $\ell \equiv 1(\bmod 6)$ positive odd integer, $\ell>1$ and $t \equiv 1(\bmod 2)$ positive integer. So, we can get $d \equiv 2(\bmod 4)$ by substituting the equivalents into the parametrization of $d$. We can easily obtain the other cases in a similar way. By using Lemma 2.3 , we put

$$
w_{R}=\frac{(2 t+1) \tau_{\ell}+7}{2}+[\frac{(2 t+1) \tau_{\ell}+7}{2} ; \underbrace{\overline{7,7, \ldots, 7}}_{\ell-1},(2 t+1) \tau_{\ell}+7],
$$

so we get

$$
\begin{gathered}
w_{R}=\left((2 t+1) \tau_{\ell}+7\right)+\frac{1}{7+\frac{1}{7+\frac{1}{1}}}=\left((2 t+1) \tau_{\ell}+7\right)+\frac{1}{7}+\cdots+\frac{1}{w_{R}}+ \\
+\frac{1}{7+\frac{1}{w_{R}}} \cdot
\end{gathered}
$$

By induction, we get

$$
w_{R}=\left((2 t+1) \tau_{\ell}+7\right)+\frac{\tau_{\ell-1} w_{R}+\tau_{\ell-2}}{\tau_{\ell} w_{R}+\tau_{\ell-1}} .
$$

If we rearrange and use the Definition 2.1 into the above equality, we have

$$
w_{R}^{2}-\left((2 t+1) \tau_{\ell}+7\right) w_{R}-\left(1+(2 t+1) \tau_{\ell-1}\right)=0 .
$$

This requires that $w_{R}=\frac{(2 t+1) \tau_{\ell}+7}{2}+\sqrt{d}$ since $w_{R}>0$. If we consider Lemma 2.3, we get

$$
w_{d}=\sqrt{d}=[\frac{(2 t+1) \tau_{\ell}+7}{2} ; \underbrace{\overline{7,7, \ldots, 7}}_{\ell-1},(2 t+1) \tau_{\ell}+7]
$$

and $\ell=\ell(d)$. This shows that the first part of proof is completed.

Now, we should determine $\epsilon_{d}, t_{d}$ and $u_{d}$ using Lemma 2.3, we get

$$
\begin{gathered}
Q_{1}=1=\tau_{1}, \quad Q_{2}=a_{1} \cdot Q_{1}+Q_{0} \Rightarrow Q_{2}=7=\tau_{2} ; \\
Q_{3}=a_{2} Q_{2}+Q_{1}=7 \tau_{2}+\tau_{1}=7^{2}+1=50=\tau_{3}, Q_{4}=\tau_{4}, \ldots
\end{gathered}
$$

So, this implies that $Q_{i}=\tau_{i}$ by using mathematical induction for every $i \geq 0$. If we substitute these values of sequence into the $\left.\epsilon_{d}=\frac{t_{d}+u_{d} \sqrt{d}}{2}=\left(a_{0}+\sqrt{d}\right) Q_{l(d)}+Q_{l(d)-1}\right\rangle 1$ and rearrange, we have

$$
\epsilon_{d}=\left(\frac{(2 t+1) \tau_{\ell}^{2}}{2}+\frac{7 \tau_{\ell}}{2}+\tau_{\ell-1}\right)+\tau_{\ell} \sqrt{d}
$$




$$
t_{d}=(2 t+1) \tau_{\ell}^{2}+7 \tau_{\ell}+2 \tau_{\ell-1} \quad \text { and } \quad u_{d}=2 \tau_{\ell}
$$

for $\epsilon_{d}, t_{d}$ and $u_{d}$. So, we complete the proof of Theorem 3.1 .

Corollary 3.3. Let $d$ be a square-free positive integer and $\ell$ be a positive integer holding that $\ell>1$ different from $0(\bmod 3)$. We assume that parametrization of $d$ is

$$
d=\frac{\left(7+\tau_{\ell}\right)^{2}}{4}+\tau_{\ell-1}+1
$$

then we obtain $d \equiv 2,3(\bmod 4)$ and

$$
w_{d}=[\frac{\tau_{\ell}+7}{2} ; \underbrace{\overline{7,7, \ldots, 7}}_{\ell-1}, \tau_{\ell}+7]
$$

and $\ell=\ell(d)$. Besides, we get following equalities

$$
\begin{gathered}
\epsilon_{d}=\left(\frac{\tau_{\ell}^{2}}{2}+\frac{7 \tau_{\ell}}{2}+\tau_{\ell-1}\right)+\tau_{\ell} \sqrt{d} ; \\
t_{d}=\tau_{\ell}^{2}+7 \tau_{\ell}+2 \tau_{\ell-1} ; \quad \text { and } u_{d}=2 \tau_{\ell} ; \\
m_{d}= \begin{cases}1, & \text { if } \ell=2 ; \\
3, & \text { if } \ell>4\end{cases}
\end{gathered}
$$

for $\epsilon_{d}, t_{d}, u_{d}$ and Yokoi's invariant $m_{d}$.

\begin{tabular}{|c|c|c|c|c|}
\hline$d$ & $\ell(d)$ & $m_{d}$ & $w_{d}$ & $\epsilon_{d}$ \\
\hline 51 & 2 & 1 & {$[7 ; \overline{7,14}]$} & $50+7 \sqrt{51}$ \\
\hline 1633642 & 5 & 3 & {$[1278 ; \overline{7,7,7,7,2556}]$} & $3257979+2549 \sqrt{1633642}$ \\
\hline 28516639237941410 & 11 & 3 & $\frac{[168868704 ;}{7,7,7,7,7,7,7,7,7,7,337737408]}$ & $\begin{array}{c}57033277246500097+ \\
+337737401 \sqrt{28516639237941410}\end{array}$ \\
\hline
\end{tabular}

Furthermore, we prepare Table 1 where fundamental unit is $\epsilon_{d}$, integral basis element is $w_{d}$ and Yokoi's invariant is $m_{d}$ for $2<\ell(d) \leq 11$. (In this Table, we will rule out $\ell(d)=4,8,10$ since $d$ is not a square-free positive integer with these periods. Besides, $d$ is not congruent to 2 or 3 (modulo 4 ) for $\ell(d)=7$ ).

Table 1

Square-free positive integers $\boldsymbol{d}$ with $2 \leq l(d) \leq 11$

Proof. This corollary is gotten if we substitute $t=0$ in Theorem 3.1. Now, we have to prove that

$$
m_{d}= \begin{cases}1, & \text { if } \ell=2 \\ 3, & \text { if } \ell>4\end{cases}
$$

If we put $t_{d}$ and $u_{d}$ into the $m_{d}$ and rearrange, then we obtain

$$
m_{d}=\left[\left[\frac{u_{d}^{2}}{t_{d}}\right]\right]=\left[\left[\frac{4 \tau_{\ell}^{2}}{\tau_{\ell}^{2}+7 \tau_{\ell}+2 \tau_{\ell-1}}\right]\right] .
$$

By using the above equality, we have $m_{d}=1$ for $\ell=2$. From the assumption since $\tau_{\ell}$ is increasing we get,

$$
4>4 .\left(1+\frac{7}{\tau_{\ell}}+\frac{2 \tau_{\ell-1}}{\tau_{\ell}^{2}}\right)^{-1}>3,988
$$

for $\ell>4$. Therefore, we obtain $m_{d}=3$ for $\ell>4$ and we have $m_{d}=\left\{\begin{array}{ll}1, & \text { if } \ell=2 ; \\ 3, & \text { if } \ell>4 .\end{array}\right.$ which completes the proof of Corollary 3.3.

Furthermore, Table 1 is gotten as a numerical results of the corollary. 
Corollary 3.4. Let $d$ be the square-free positive integer and $\ell$ be a positive integer such that $\ell$ is not congruent to 0 as for $(\bmod 3), \ell>1$. We suppose that parametrization of $d$ is

$$
d=\frac{\left(7+3 \tau_{\ell}\right)^{2}}{4}+3 \tau_{\ell-1}+1
$$

then, we obtain $d \equiv 2(\bmod 4)$ and

$$
w_{d}=[\frac{3 \tau_{\ell}+7}{2} ; \underbrace{7,7, \ldots, 7}_{\ell-1}, 3 \tau_{\ell}+7]
$$

and $\ell=\ell(d)$. Moreover, we have following equalities:

$$
\begin{gathered}
\epsilon_{d}=\left(\frac{3 \tau_{\ell}^{2}}{2}+\frac{7 \tau_{\ell}}{2}+\tau_{\ell-1}\right)+\tau_{\ell} \sqrt{d} ; \\
t_{d}=3 \tau_{\ell}^{2}+7 \tau_{\ell}+2 \tau_{\ell-1} \quad \text { and } \quad u_{d}=2 \tau_{\ell}
\end{gathered}
$$

$m_{d}=1$ for $\ell \geq 7$ for $\epsilon_{d}, t_{d}, u_{d}$ and Yokoi's invariant $m_{d}$. Besides, we state the following Table 2 , where fundamental unit is $\epsilon_{d}$, integral basis element is $w_{d}$ and Yokoi's invariant is $m_{d}$ for $2<\ell(d) \leq 13$.

Table 2

Square-free positive integers $\boldsymbol{d}$ with $l(d)=7$ or $l(d)=13$

\begin{tabular}{|c|c|c|c|c|}
\hline$d$ & $\ell(d)$ & $m_{d}$ & $w_{d}$ & $\epsilon_{d}$ \\
\hline 37996589930 & 7 & 1 & {$[194927 ; \overline{7,7,7,7,7,7,389854}]$} & $25330586923+129949 \sqrt{37996589930}$ \\
\hline 667032581096785339826 & 13 & 1 & $\left.\frac{[25826973905 ;}{7,7, \ldots, 7,51653947810}\right]$ & $\begin{array}{c}444688387335182490505+ \\
+17217982601 \sqrt{667032581096785339826}\end{array}$ \\
\hline
\end{tabular}

Proof. Corollary is obtained if we substitute $t=1$ in Theorem 3.1 . We should prove that $m_{d}=1$ for $\ell \geq 7$. If we put $t_{d}$ and $u_{d}$ into the $m_{d}$ and rearrange, then we obtain

$$
2>4 \cdot\left(3+\frac{7}{\tau_{\ell}}+\frac{2 \tau_{\ell-1}}{\tau_{\ell}^{2}}\right)^{-1}>1,333
$$

for $\ell \geq 7$ since $\tau_{\ell}$ is increasing sequence.By using the above equality, we have $m_{d}=1$ for $\ell \geq 7$. Also, Table 2 is given as an illustration of this corollary.

Corollary 3.5. We assume that $d$ and $\ell$ are defined as in Theorem 3.1. If we choose the parametrization of $d$ as

then $d \equiv 2,3(\bmod 4)$ and

$$
d=\frac{\left(7+5 \tau_{\ell}\right)^{2}}{4}+5 \tau_{\ell-1}+1
$$

$$
w_{d}=[\frac{5 \tau_{\ell}+7}{2} ; \underbrace{\overline{7,7, \ldots, 7}}_{\ell-1}, 5 \tau_{\ell}+7]
$$

with $\ell=\ell(d)$. Also, we have the following equalities:

$$
\begin{gathered}
\epsilon_{d}=\left(\frac{5 \tau_{\ell}^{2}}{2}+\frac{7 \tau_{\ell}}{2}+\tau_{\ell-1}\right)+\tau_{\ell} \sqrt{d} \\
t_{d}=5 \tau_{\ell}^{2}+7 \tau_{\ell}+2 \tau_{\ell-1} \quad \text { and } \quad u_{d}=2 \tau_{\ell}, \\
n_{d}=1
\end{gathered}
$$

for $\ell \geq 2$. 
Additionally, we prepare the Table 3 where fundamental unit is $\epsilon_{d}$, integral basis element is $w_{d}$ and and Yokoi's invariant is $n_{d}$ for $2 \leq \ell(d) \leq 11$. (In this table, we rule out both $\ell(d)=10$ since $d$ is not a square-free positive integer in this period and also $d$ is not congruent to 2 or 3 (modulo4) for $\ell(d)=7$ ).

Table 3

Square-free positive integers $\boldsymbol{d}$ with $2 \leq l(d) \leq 11$

\begin{tabular}{|c|c|c|c|c|}
\hline$d$ & $\ell(d)$ & $n_{d}$ & $w_{d}$ & $\epsilon_{d}$ \\
\hline 447 & 2 & 1 & {$[21 ; \overline{7,42}]$} & $148+7 \sqrt{447}$ \\
\hline 803067 & 4 & 1 & {$[896 ; \overline{7,7,7,1792}]$} & $319922+357 \sqrt{803067}$ \\
\hline 40655162 & 5 & 1 & {$[6376 ; \overline{7,7,7,7,12752}]$} & $16252781+2549 \sqrt{40655162}$ \\
\hline 5380595841067 & 8 & 1 & {$[2319611 ; \overline{7,7,7,7,7,7,7,4639222}]$} & $2152234959022+927843 \sqrt{5380595841067}$ \\
\hline 712915956360881002 & \multirow{2}{*}{11} & \multirow{2}{*}{1} & $\left.\frac{[844343506 ;]}{7,7,7,7,7,7,7,7,7,7,1688687012}\right]$ & $+337737401 \sqrt{7129159563608381002}$ \\
\hline
\end{tabular}

Proof. It is gotten if we substitute $t=2$ in Theorem 3.1. Let's prove that Yokoi's d- invariant is $n_{d}=1$ for $\ell \geq 2$.

We know from H. Yokoi's references [16-19] that $n_{d}=\left[\left[\frac{t_{d}}{u_{d}^{2}}\right]\right]$. If we substitute $t_{d}$ and $u_{d}$ into $n_{d}$, then we get

$$
n_{d}=\left[\left[\frac{t_{d}}{u_{d}^{2}}\right]\right]=\left[\left[\frac{5 \tau_{\ell}^{2}+7 \tau_{\ell}+2 \tau_{\ell-1}}{4 \tau_{\ell}^{2}}\right]\right]=1,
$$

since $\tau_{\ell}$ is increasing and $1<\frac{5}{4}+\frac{7}{4 \tau_{\ell}}+\frac{\tau_{\ell-1}}{2 \tau_{\ell}^{2}}<1,510$ for $\ell \geq 2$. Therefore, we obtain $n_{d}=1$ for $\ell \geq 2$. As illustration, we give Table 3 .

Theorem 3.6. Let $d$ be a square-free positive integer and $\ell>1$ be a positive integer.

(i) We suppose

$$
d=\left(2 t \tau_{\ell}+7\right)^{2}+8 t \tau_{\ell-1}+4
$$

for $t>0$ positive integer. In this case, we obtain that $d \equiv 1(\bmod 4)$ and

$$
w_{d}=[t \tau_{\ell}+4 ; \underbrace{\overline{7,7, \ldots, 7}}_{\ell-1}, 2 t \tau_{\ell}+7]
$$

and $\ell=\ell(d)$. Moreover, in this case it holds

$$
t_{d}=2 t \tau_{\ell}^{2}+7 \tau_{\ell}+2 \tau_{\ell-1} \quad \text { and } \quad u_{d}=\tau_{\ell}
$$

for $\epsilon_{d}=\frac{t_{d}+u_{d} \sqrt{d}}{2}$.

(ii) If $\ell \equiv 0(\bmod 3)$ and

$$
d=\left(t \tau_{\ell}+7\right)^{2}+4 t \tau_{\ell-1}+4
$$

for $t>0$ positive odd integer then $d \equiv 1(\bmod 4)$ and

$$
w_{d}=[\frac{t}{2} \tau_{\ell}+4 ; \underbrace{\overline{7,7, \ldots, 7}, t \tau_{\ell}+7}_{\ell-1}]
$$

and $\ell=\ell(d)$. Furthermore, in this case

$$
t_{d}=t \tau_{\ell}^{2}+7 \tau_{\ell}+2 \tau_{\ell-1} \quad \text { and } \quad u_{d}=\tau_{\ell}
$$

hold for $\epsilon_{d}=\frac{t_{d}+u_{d} \sqrt{d}}{2}$. 
Remark 3.7. For the case (ii) in Theorem 3.6, it is clear that $\tau_{\ell}$ is odd number if $\ell$ is not divided by 3 . For the case $(i i)$, assume that $\ell$ is not divided by 3 . Then we get $d$ is not integer if we put $t$ positive odd integer into the parametrization of $d$. Besides, if we consider $t$ is positive even integer, then the parametrization of $d$ will be the case $(\mathrm{i})$. So, we approve that $\ell \equiv 0(\bmod 3)$ and $t$ is positive odd integer in the case (ii).

Proof. (1) It is clear that $d \equiv 1(\bmod 4)$ holds since $\left(2 t \tau_{\ell}+7\right)^{2}$ is odd integer for any $t>0$ and $\ell>1$ positive integers. We prove the theorem in a similar to Theorem 3.1. From Lemma 2.2, we know that $\omega_{d}=\frac{1+\sqrt{d}}{2}$, $a_{0}=\left[\left[\omega_{d}\right]\right], \omega_{R}=a_{0}-1+\omega_{d}$.

Considering above equations, we have

$$
w_{R}=t \tau_{\ell}+3+[t \tau_{\ell}+4 ; \underbrace{\overline{7,7, \ldots, 7}}_{\ell-1}, 2 t \tau_{\ell}+7]
$$

so we get

$$
w_{R}=\left(2 t \tau_{\ell}+7\right)+\frac{1}{7+\frac{1}{7+\frac{1}{+\frac{1}{7+\frac{1}{w_{R}}}}}}=\left(2 t \tau_{\ell}+7\right)+\frac{1}{7}+\cdots+\frac{1}{w_{R}} .
$$

Rearranging and using Lemma 2.2 with Definition 2.1 into the above equality, we obtain

$$
w_{R}^{2}-\left(2 t \tau_{\ell}+7\right) w_{R}-\left(1+2 t \tau_{\ell-1}\right)=0 .
$$

This requires that $w_{R}=\left(t \tau_{\ell}+4\right)-1+\frac{1+\sqrt{d}}{2}$ since $w_{R}>0$. If we consider Lemma 2.1 , we get

$$
w_{d}=[t \tau_{\ell}+4 ; \underbrace{\overline{7,7, \ldots, 7}, 2 t \tau_{\ell}+7}_{\ell-1}]
$$

and $\ell=\ell(d)$.

We obtained that $Q_{i}=\tau_{i}$ by using mathematical induction for all $i \geq 0$ in Theorem 3.1. Now, we get $t_{d}$ and $u_{d}$ using Lemma 2.2 as follows

$$
t_{d}=2 t \tau_{\ell}^{2}+7 \tau_{\ell}+2 \tau_{\ell-1} \quad \text { and } \quad u_{d}=\tau_{\ell}
$$

for $\epsilon_{d}=\frac{t_{d}+u_{d} \sqrt{d}}{2}$. This shows that the first part of proof is completed.

(2) If we assume that $\ell \equiv 0(\bmod 3)$ and the parametrization of

$$
d=\left(t \tau_{\ell}+7\right)^{2}+4 t \tau_{\ell-1}+4
$$

for $t>0$, then we have $d \equiv 1(\bmod 4)$ since $\tau_{\ell}$ is even integer. By taking $\frac{t}{2}$ instead of $t$ into the case $(1)$, we get

$$
w_{d}=[\frac{t}{2} \tau_{\ell}+4 ; \underbrace{\overline{7,7, \ldots, 7}}_{\ell-1}, t \tau_{\ell}+7]
$$

and $\ell=\ell(d)$ for $\ell \equiv 0(\bmod 3)$. Furthermore,

$$
t_{d}=t \tau_{\ell}^{2}+7 \tau_{\ell}+2 \tau_{\ell-1} \quad \text { and } \quad u_{d}=\tau_{\ell}
$$

hold for $\epsilon_{d}=\frac{t_{d}+u_{d} \sqrt{d}}{2}$ which completes the proof.

Corollary 3.8. Let $d$ be the square-free positive integer and $\ell>1$ is a positive integer. We assume that parametrization of $d$ is

$$
d=\left(2 \tau_{\ell}+7\right)^{2}+8 \tau_{\ell-1}+4
$$


then we obtain $d \equiv 1(\bmod 4)$ and

$$
w_{d}=[\tau_{\ell}+4 ; \underbrace{\overline{7,7, \ldots, 7}, 2 \tau_{\ell}+7}_{\ell-1}]
$$

and $\ell=\ell(d)$. Moreover, we have

$$
t_{d}=2 \tau_{\ell}^{2}+7 \tau_{\ell}+2 \tau_{\ell-1} \quad \text { and } \quad u_{d}=\tau_{\ell}
$$

for $\epsilon_{d}=\frac{t_{d}+u_{d} \sqrt{d}}{2}$ and, Yokoi's invariant $n_{d}$ is determined as follows:

$$
n_{d}= \begin{cases}3, & \text { if } \ell=2 \\ 2, & \text { if } \ell>2\end{cases}
$$

Also, we give Table 4 where fundamental unit is $\epsilon_{d}$, integral basis element is $w_{d}$ and Yokoi's invariant is $n_{d}$ for $2 \leq \ell(d) \leq 11$. (In this table, we rule out $\ell(d)=4,5,10$ since $d$ is not a square-free positive integer with these periods).

Table 4

Square-free positive integers $\boldsymbol{d}$ with $2 \leq l(d) \leq 11$

\begin{tabular}{|c|c|c|c|c|}
\hline$d$ & $\ell(d)$ & $n_{d}$ & $w_{d}$ & $\epsilon_{d}$ \\
\hline 453 & 2 & 3 & {$[11 ; \overline{7,21}]$} & $(149+7 \sqrt{453}) / 2$ \\
\hline 11509 & 3 & 2 & {$[54 ; \overline{7,7,107}]$} & $(5364+50 \sqrt{11509}) / 2$ \\
\hline 1325490045 & 6 & 2 & {$[18204 ; \overline{7,7, \ldots 7,36407}]$} & $(337744431245+129949 \sqrt{67550754629}) / 2$ \\
\hline 67550754629 & 7 & 2 & {$[129953 ; \overline{7,7, \ldots, 7,259905}]$} & $(1721792020097+927843 \sqrt{3443597549845) / 2}$ \\
\hline 3443597549845 & 8 & 2 & {$[927847 ; 7,7, \ldots, 7,1855693]$} & $(228133106527234995+$ \\
\hline 175554743008597 & 9 & 2 & {$[6624854 ; \overline{7,7, \ldots, 7,13249707}]$} & $(87777323274636+6624850 \sqrt{175554743008597}) / 2$ \\
\hline 456266217972000829 & 11 & 2 & {$[337737405 ;$} & $337737401 \sqrt{456266217972000829}) / 2$ \\
\hline
\end{tabular}

Proof. The corollary is had if we substitute $t=1$ into the case (1) in Theorem 3.6. Let's show that

$$
n_{d}= \begin{cases}3, & \text { if } \ell=2 \\ 2, & \text { if } \ell>2\end{cases}
$$

If we put $t_{d}$ and $u_{d}$ into the $n_{d}$ and rearrange, then we obtain

$$
n_{d}=\left[\left[\frac{t_{d}}{u_{d}^{2}}\right]\right]=\left[\left[\frac{2 \tau_{\ell}^{2}+7 \tau_{\ell}+2 \tau_{\ell-1}}{\tau_{\ell}^{2}}\right]\right] .
$$

By using the above equality, we have $n_{d}=3$ for $\ell=2$. From the assumption since $\tau_{\ell}$ is increasing sequence, we get,

$$
2,1456 \geq\left(2+\frac{7}{\tau_{\ell}}+\frac{2 \tau_{\ell-1}}{\tau_{\ell}^{2}}\right)>2
$$

for $\ell>2$. Therefore, we obtain $n_{d}=\left\{\begin{array}{ll}3, & \text { if } \ell=2 ; \\ 2, & \text { if } \ell>2 .\end{array}\right.$ Then Corollary 3.8 is proved. To give numerical examples for Corollary 3.8, we prepare Table 4 .

Corollary 3.9. Let $d$ be the square-free positive integer and $\ell>1$ is a positive integer holding that $\ell \equiv$ $0(\bmod 3)$. We assume that parametrization of $d$ is

$$
d=\left(\tau_{\ell}+7\right)^{2}+4 \tau_{\ell-1}+4
$$

then we have $d \equiv 1(\bmod 4)$ and

$$
w_{d}=[\frac{\tau_{\ell}}{2}+4 ; \underbrace{\overline{7,7, \ldots, 7}}_{\ell-1}, \tau_{\ell}+7]
$$


and $\ell=\ell(d)$. Moreover, we have

$$
t_{d}=\tau_{\ell}^{2}+7 \tau_{\ell}+2 \tau_{\ell-1} \quad \text { and } \quad u_{d}=\tau_{\ell}
$$

for $\epsilon_{d}=\frac{t_{d}+u_{d} \sqrt{d}}{2}$ and, Yokoi's invariant $n_{d}=1$.

Besides, we prepare Table 5 where fundamental unit is $\epsilon_{d}$, integral basis element is $w_{d}$ and Yokoi's invariant is $n_{d}$ for $3 \leq \ell(d) \leq 12$ (in this Table, we rule out $\ell(d)=9$ since $d$ is not a square-free positive integer with these periods).

Table 5

Square-free positive integers $\boldsymbol{d}$ with $3 \leq l(d) \leq 12$

\begin{tabular}{|c|c|c|c|c|}
\hline$d$ & $\ell(d)$ & $n_{d}$ & $w_{d}$ & $\epsilon_{d}$ \\
\hline 3281 & 3 & 1 & {$[29 ; 7,7,57]$} & $(2864+50 \sqrt{3281) / 2}$ \\
\hline 331505049 & 6 & 1 & {$[9104 ; 7,7, \ldots, 7,18207]$} & $(331372498+18200 \sqrt{331505049}) / 2$ \\
\hline 58151567292136400057 & 12 & 1 & $\left.\frac{[1205731804 ;]}{7,7, \ldots 7,2411463607}\right]$ & $(5815156711680680002+$ \\
\hline
\end{tabular}

Proof. If we substitute $t=1$ into the case (2) in Theorem 3.6, we have the Corollary 3.9. Let's prove that $n_{d}=1$. If we put $t_{d}$ and $u_{d}$ into the $n_{d}$ and rearrange, then we obtain

$$
n_{d}=\left[\left[\frac{t_{d}}{u_{d}^{2}}\right]\right]=\left[\left[\frac{\tau_{\ell}^{2}+7 \tau_{\ell}+2 \tau_{\ell-1}}{\tau_{\ell}^{2}}\right]\right] .
$$

From the assumption since $\tau_{\ell}$ is increasing sequence, we get

$$
1,1416 \geq\left(1+\frac{7}{\tau_{\ell}}+\frac{2 \tau_{\ell-1}}{\tau_{\ell}^{2}}\right)>1
$$

for $\ell \geq 3$ which completes the proof of the Corollary 3.9. We prepare Table 5 as an numerical illustrations of Corollary 3.9.

Corollary 3.10. Let $d$ be a square-free positive integer congruent to modulo 4 . If we suppose that $d$ is holding the conditions of Theorem 3.6, then always satisfy that Yokoi's invariant $n_{d}$ is different from zero. It means that $m_{d}=0$.

Proof. It can be proven as similar of Corollary 3.2 in [15].

Remark 3.11. We should say that the present paper has got the most general theorems for given type real quadratic fields. Also, we can obtain infinitely many values of $d$ which corresponds to $Q(\sqrt{d})$ and determine the structures of such fields by using our results.

\section{References}

1 ElezoviÂ, 'c. (1997). A note on continued fractions of quadratic irrationals. Math. Commun., 2, 27-33.

2 Jeongho, P. (2015). Notes on Quadratic Integers And Real Quadratic Number Fields, arXiv.1208.5353V5/math.NT].

3 Benamar, H., Chandoul, A., \& Mkaouar, M. (2015). On The Continued Fraction Expansion of Fixed Period in Finite Fields, Canad. Math. Bull, 704-712.

4 Badziahin, D., \& Shallit, J. (2016). An unusual continued fraction, Proc. Amer. Math. Soc., 144, 18871896.

5 Zhang, Z., \& Yue, Q. (2014). Fundamental units of real quadratic of odd class number. Journal of Number Theory, 137, 122-129.

6 Tomita, K. (1995). Explicit representation of fundamental units of some quadratic fields. Proc. Japan Acad., 71, Ser. A, 2, 41-43. 
7 Clemens, L.E., Merill, K.D., \& Roeder, D.W. (1995). Continues fractions and series. Journal of Number Theory 54, 309-317.

8 Louboutin, S. (1988). Continued Fraction and Real Quadratic Fields. Journal Number Theory, 30, 167176.

9 Kawamoto, F., \& Tomita, K. (2008). Continued fraction and certain real quadratic fields of minimal type. Journal Math. Soc. Japan, 60, 865-903.

10 Sasaki, R. (1986). A characterization of certain real quadratic fields. Proc. Japan Acad., 62, Ser. A, 3, 97-100.

11 Mollin R.A. (1996). Quadratics, CRC Press, Boca Rato, FL.

12 Williams, K.S., \& Buck, N. (1994). Comparison of the lengths of the continued fractions of $\sqrt{\mathrm{D}}$ and $\frac{1}{2}(1+\sqrt{\mathrm{D}})$, Proc. Amer. Math. Soc., 12(4), 995-1002.

13 Özer, Ö. (2016). On Real Quadratic Number Fields Related With Specific Type of Continued Fractions. Journal of Analysis and Number Theory, 4(2), 85-90.

14 Özer, Ö. (2016). Notes On Especial Continued Fraction Expansions and Real Quadratic Number Fields. Kirklareli University Journal of Engineering and Science, 2(1), 74-89.

15 Özer, Ö. (2018). A Study on the Fundamental Unit of Certain Real Quadratic Number Fields. Turkish Journal of Analysis and Number Theory, 6(1), 1-8.

16 Yokoi, H. (1990). The fundamental unit and class number one problem of real quadratic fields with prime discriminant. Nagoya Math. J., 120, 51-59.

17 Yokoi, H. (1993). A note on class number one problem for real quadratic fields. Proc. Japan Acad., 69, Ser. A, 22-26.

18 Yokoi, H. (1991). The fundamental unit and bounds for class numbers of real quadratic fields. Nagoya Math. J., 124, 181-197.

19 Yokoi, H. (1993). New invariants and class number problem in real quadratic fields. Nagoya Math. J., 132, $175-197$.

20 Olds, C.D. (1963). Continued Functions, New York: Random House.

21 Perron, O. (1950). Die Lehre von den Kettenbrüchen. New York: Chelsea, Reprint from Teubner, Leipzig.

22 Sierpinski, W. (1964). Elementary Theory of Numbers. Warsaw: Monografi Matematyczne.

23 Tomita, K., \& Yamamuro, K. (2002). Lower bounds for fundamental units of real quadratic fields. Nagoya Math. J., 166, 29-37.

\section{Ӧ. Ӧзер, Д. Беллауар \\ Нақты квадраттық өрістің арнаулы түрі бойынша кейбір нәтижелер}

Мақалада нақты квадраттық өрістер бүтін еркін оң $w_{d}=[a_{0} ; \underbrace{7,7, \ldots, 7}_{\ell-1}, a_{\ell}]$ тізбекті бөлшектің жіктелу түрімен қоса, $d$ квадраттарымен сәйкес келетіні анықталды. Сондай-ақ негізгі бірлік және Йокой
бірліктері анықталып, $n_{d}$ және $m_{d} d$-инварианттары $w_{d}$ бөлшегін үздіксіз жіктеуге қолданылды, мұндағы $\ell(d) w_{d}$ - кезең ұзындығы $Q(\sqrt{d})$ нақты квадраттық сандар өрісі түрі үшін. Авторлар нақты квадраттық өрістің бірлік группасы туындайтын іргелі бірлік теориясын жаңартып, нақты квадраттық өрісте бүтінсанды базистік элементтің үздіксіз бөлшекті жіктелуінің ерекше түрін анықтаған.

Kiлm сөздер: тізбекті бөлшек, квадраттық өріс, негізгі бірлік, Йокой инварианттары, бүтінсанды базистік элемент. 
Ӧ. Ӧзер, Д. Беллауар

\section{Некоторые результаты по специальному типу вещественных квадратичных полей}

В статье определено, что действительные квадратичные поля совпадают с целыми свободными положительными квадратами $d$, включая форму разложения цепной дроби $w_{d}=[\underbrace{a_{0} ; \underbrace{7,7, \ldots, 7}, a_{\ell}}_{\ell-1}]$.

Кроме того, определены основные единицы и единицы Йокой, $d$-инварианты $n_{d}$ и $m_{d}$ применительно к непрерывному разложению дроби $w_{d}$, где $\ell(d)$ - длина периода $w_{d}$ для такого типа поля действительных квадратичных чисел $Q(\sqrt{d})$. Авторами статьи улучшена теория фундаментальной единицы, которая порождает единичную группу вещественных квадратичных полей, а также определена особая форма непрерывного дробного разложения целочисленного базисного элемента в вещественных квадратичных полях.

Ключевые слова: цепная дробь, квадратичное поле, основная единица, инварианты Йокой, целочисленный базисный элемент. 